\title{
Leaf-litter amount as a factor in the structure of a ponerine ants community (Hymenoptera, Formicidae, Ponerinae) in an eastern Amazonian rainforest, Brazil
}

\author{
Alexandro Herbert dos Santos Bastos ${ }^{1} \&$ Ana Yoshi Harada ${ }^{1}$ \\ 'Coordenação de Pesquisas em Zoologia, Museu Paraense Emílio Goeldi, Caixa Postal 390, Belém-PA, Brasil. ahsbastos@yahoo.com.br; \\ ahara@museu-goeldi.br
}

\begin{abstract}
Leaf-litter amount as a factor in the structure of a ponerine ants community (Hymenoptera, Formicidae, Ponerinae) in an eastern Amazonian rainforest, Brazil. Leaf-litter may be an important factor in structuring ponerine ant communities (Hymenoptera, Formicidae, Ponerinae) in tropical rainforests. We specifically examined how leaf-litter affects the structure of a ponerine ant community in primary Amazonian rainforest sites at the Ferreira Penna Scientific Station, Pará, Brazil. A total of 53 species belonging to eight genera of three ponerine tribes were collected with mini-Winkler extractors. The amount of leaf-litter positively affected the abundance and richness of the ponerine ant community, and also influenced species composition. Nearby samples often had low species similarity, especially when adjacent samples differed in the amount of leaf-litter. Leaf-litter availability in Amazonian primary forests is a key factor for distribution of ground-dwelling ponerine species, even at small scales.
\end{abstract}

KEYWORDS. Amazonia; Caxiuanã; leaf-litter; ponerine ants; species distribution.

RESUMO. Efeito da quantidade de serapilheira sobre a estrutura de uma comunidade de formigas ponerinae (Hymenoptera, Formicidae, Ponerinae) em uma floresta tropical da Amazônia Oriental, Brasil. Analisou-se o efeito da serapilheira sobre a estrutura da comunidade de formigas Ponerinae em áreas de floresta amazônica primária, localizadas na Estação Científica Ferreira Penna, Pará, Brasil. Foram coletadas 53 espécies de formigas, pertencentes a oito gêneros e três tribos da subfamília Ponerinae, utilizando-se extratores de mini-Winkler. A quantidade de serapilheira afetou positivamente a abundância e riqueza, bem como esteve associada à composição de espécies dessas formigas. Amostras próximas apresentaram baixa similaridade faunística, especialmente quando continham quantidades divergentes de serapilheira. Sugere-se, então, que a distribuição dessas formigas depende da disponibilidade de recursos na serapilheira em floresta primária amazônica, mesmo em pequena escala.

PALAVRAS-CHAVE. Amazônia; Caxiuanã; distribuição de espécies; formigas ponerines; serapilheira.

The heterogeneous distribution of resources affects the foraging, nesting and diversity of ants in tropical rainforests (McGlynn \& Kirksey 2000; Armbrecht et al. 2004; McGlynn 2006). In structurally complex ecosystems, such as tropical rainforests, ants are among the most important biological components. For instance, one-third of the arthropod biomass in Amazonian rainforests is composed of ants and termites (Fittkau \& Klinge 1973). On the whole, disturbance effects on ant communities have been related to human activities or to different vegetation and soil types (Philpott et al. 2010). Compared with those modifications, much less is understood about natural influences on small scale variation on ant assemblages (Folgarait 1998; Mertl et al. 2009). In Neotropical wet forests, ground-dwelling ant species distributions are affected by local variations in food availability, nest sites, moisture contents and flooding (Levings 1983; Benson \& Harada 1988; Majer \& Delabie 1994; Mertl et al. 2009).

The leaf-litter layer of tropical rainforests is a conspicuous habitat for the fauna and is still little known. The processes of mineralization and decomposition of organic matter take place in the leaf-litter, and thereby influence the physical and chemical proprieties of forest soils, nutrient availability and the di- versity of fungi, plants and others soil organisms (Sayer 2006). The amount of leaf-litter varies significantly over time and space, since litter fall rates are associated with weather, seasonality, topography, soil composition and species distribution (Sayer 2006; Kaspari \& Yanoviak 2008). This variation in leaf-litter may affect leaf-litter ant communities by several pathways. In certain tropical habitats, high ant species density is associated with greater leaf-litter depths (Delabie \& Fowler 1995). In the leaf-litter and on the soil surface of tropical rainforests, the patterns of ant nesting and foraging are correlated to the spatial and temporal variability of the physicalchemical composition of litter, litter density in soil and vegetation composition and structure (Levings 1983; Vasconcelos 1999; McGlynn \& Kirksey 2000; Vasconcelos et al. 2003). Further, the leaf-litter is an environment with an abundance of arthropods that are potential prey items for ants and a series of microhabitats that are favorable nest sites to ants (Benson \& Harada 1988; Silva \& Silvestre 2004).

The ponerines, after the myrmicines, are the most conspicuous and diverse ground-dwelling ants from tropical rainforests soil and leaf-litter (Overal et al. 1997; Brühl et al. 1999; Silva \& Silvestre 2004; Santos et al. 2006; Quiroz- 
Robledo \& Valenzuela-González 2007; Schütte et al. 2007; Schmidt 2008). The ponerine ants are ecologically crucial, since they prey on various kinds of invertebrates and nest or forage in leaf-litter, rotten logs or soil. These ants are common in humid forest areas, but may be found in dry forest with seasonal rainfall (Lattke, 2003; Quiroz-Robledo \& Valenzuela-González 2007). The few ecological surveys available emphasize the influence of environmental variables on ponerine ant species composition, richness and abundance in Amazonia. Fagundes (2003) demonstrated the positive effects of soil clay percentage and litter amount on ant abundance for Ponerinae, considering the number of individuals.

In this paper we document the structure and species distribution of a ponerine ants community in the leaf-litter of six primary eastern Amazonian forest sites. Specifically, we evaluated the influence of leaf-litter amount on the ponerine ant species composition, richness and abundance. Our results add important information about knowledge of the ant faunas from discrete areas in Amazonia and provide baseline data for researchers in faunal management and conservation.

\section{MATERIAL AND METHODS}

Study site. Fieldwork was conducted during October 2003 and January 2004 at six 100 ha primary forests sites (Integrated management area - IMA - I, II, III, IV, V and VI) of the Tropical Ecology Assessment and Monitoring Project (TEAM)/Caxiuanã at Ferreira Penna Scientific Station (ECFPn) in the Caxiuanã National Forest, municipality of Melgaço, Pará state, Brazil (01³8'14"S to $01^{\circ} 47^{\circ} 41^{\prime \prime}$; $51^{\circ} 20^{\prime} 00^{\prime \prime} \mathrm{W}$ to $\left.51^{\circ} 36^{\prime} 33^{\prime \prime} \mathrm{W}\right)$. The station is managed by the Museu Paraense Emílio Goeldi (MPEG), and is situated approximately $400 \mathrm{~km}$ west of Belém (Lisboa 2002) (Fig. 1).

In this region, rainfall determines a distinct rainy season (December to May, with a monthly average $>200 \mathrm{~mm}$ ) and a dry season (June to November, with a monthly average $<180$ $\mathrm{mm}$, just $60 \mathrm{~mm}$ in the drier months of October and November) (Costa \& Moraes 2002). According to Lisboa (2002), the area of Caxiuanã National Forest may be divided into three basic environments: unflooded forest ("terra firme") that compose $80 \%$, and the flooded forests ("várzea" and "igapó") that correspond to $20 \%$.

Sampling Protocol. According to the ant methodology protocol of the TEAM Project, each plot of 100 ha was divided into four equal 25 ha quadrants. In each quadrant one $100 \mathrm{~m}$ transect line was randomly established where ten subsamples, taken at $10 \mathrm{~m}$ intervals, were taken. The same transect was not repeated during the study. Accordingly, 240 subsamples from 24 transects among the 6 plots were collected per collection period (during 15 days), totaling 480 subsamples and 48 transects in the two fieldwork trips. The sampling units consisted of transects $(n=48)$ to attest the sample independence at each site.

Invertebrates were extracted from leaf-litter samples using the mini-Winkler method (Bestelmeyer et al. 2000). Each $1 \mathrm{~m}^{2}$ leaf-litter sample (transect subsample) was collected and sifted during $60 \mathrm{~s}$. After sifting, the material was transposed to a mesh-bag ( $0.4 \mathrm{~cm}$ of gap diameter) and placed into a miniWinkler extractor during a 48-hour period to collect the ants.

The amount of sifted leaf-litter per subsample was recorded, from which the leaf-litter volume per transect was determined. Before being placed into a mesh-bag, the sifted leaf-litter volume was measured with a $500 \mathrm{ml}$ beaker. All the ponerine ants were identified to species or morphospecies. Voucher specimens were deposited in the Invertebrates Collection of the MPEG.

Data analyses. The frequency of occurrence of species at all transects within a site was recorded rather than number of individuals as an indicator of abundance. This method is a better parameter for ants, because of their sociality procedure (Romero \& Jaffe 1989). In view of that, we had no ponerine ants abundance per sample (transect), but per site $(n=12)$. The overall abundance per ponerine species consisted of occurrence frequency (number of records) from all transects. Species richness was assessed as the number of species collected in each transect.

To evaluate the effects of leaf-litter on ponerine ant species abundance and richness, we used linear regression analysis. The total volume of leaf-litter per plot $(n=12)$ and per transect $(n=48)$ were the predictive variables for ponerine ant abundance and species richness, respectively.

Variation in species composition was analyzed using an ordination method. The sample (transect) species incidence (presence or absence) matrix was subjected to non-metric multidimensional scaling (NMDS) for an ordination with a two-dimension solution, which used Jaccard distance as the association measure. The NMDS is a robust ordination method for non-linear data, and its performance, at few dimensions, has been considered more precise than other indirect ordination techniques. A stress value is give by the array of obtained versus observed ranks, such that values approaching zero give better resolution between ordination dimensions. The $r^{2}$ values are the coefficients of determination between distances along each ordination axis and the original distances. These values indicate how representative are the axes to the grouping or partition of the points in the obtained configuration (Hammer et al. 2008). We also used the species incidence matrix to calculate the Jaccard index of similarity, a standard index for binary data, from which we analyzed the species composition variation per sample.

Pearson's linear correlation was used to analyze the relationship between leaf-litter volume and ponerine ant species composition. Since the composition data is not continuous, we submitted the ordination scores (NMDS) of the first two axes, representing the variation in species composition. The predictive variable was leaf-litter volume.

To verify the normal distribution assumptions of all variables, we used the Shapiro-Wilks test. Data on leaf-litter volume were square-root transformed, but no transformation was needed for data on species composition (ordination scores), species abundance or species richness. All analysis were performed with the PAST v. 1.99 statistic package (Hammer et al. 2010). 


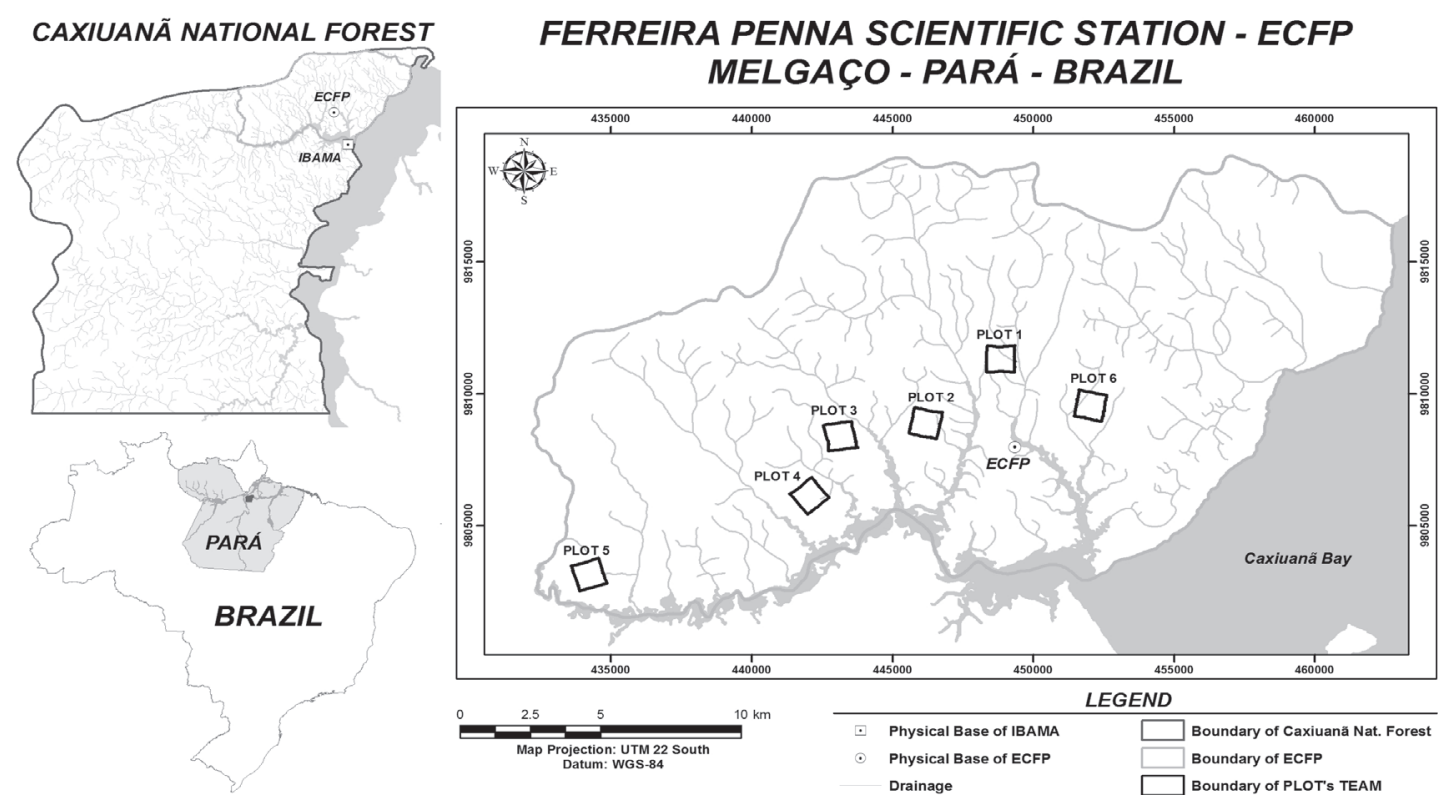

Fig. 1. Map showing location of the study area (ECFPn) and the distribution of sampling sites (PLOT = IMA) within that area, in Caxiuanã National Forest, Pará State, Brazil.

\section{RESULTS}

Species abundance and richness. A total of 320 records of ponerine ants were collected in 48 samples. We identified 53 morphospecies (hereafter called only species) (2854 specimens) of three tribes and eight genera (Table I). Only 24 species name were identified, and the others (29) were morpho-typed.

Among all genera, Hypoponera was the highest in both abundance and number of species (188 occurrences; 21 species), followed by Pachycondyla (57; 15), Odontomachus (35; 8), Anochetus (31;4), Leptogenys (3; 2) and Thaumatomyrmex $(4 ; 1)$. Platythyrea and Simopelta were represented by only

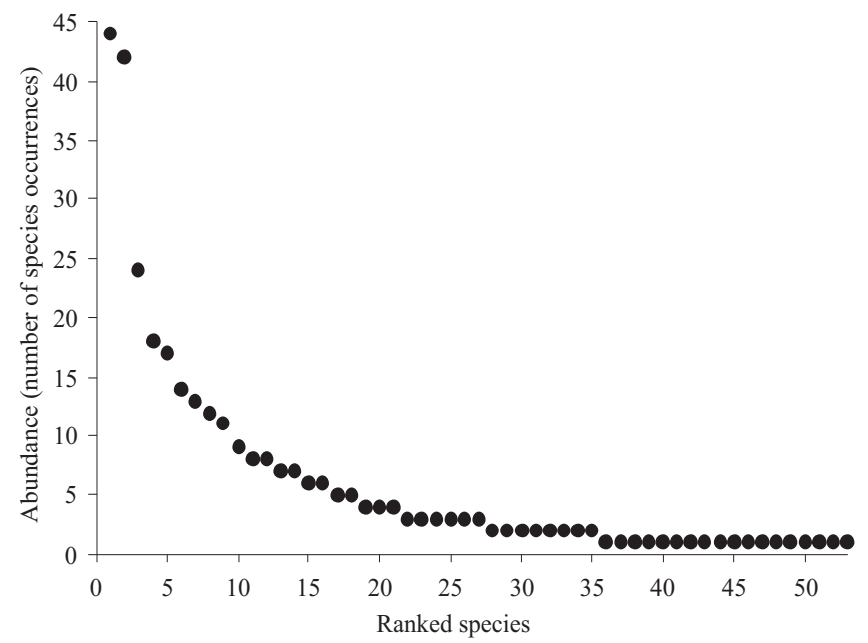

Fig. 2. Overall abundance of ponerine ant species (species were ranked) in leaf-litter layer of primary rainforests in ECFPn, Caxiuanã, Brazil. one species at one occurrence. Hypoponera and Pachycondyla together accounted almost $68 \%$ of species (36) and were over $76 \%$ (245) of the total abundance.

Seven $(13.21 \%)$ of the 53 species collected represented more than $50 \%$ of the total abundance (Hypoponera sp.1, Hypoponera sp.2, Hypoponera sp.6, Hypoponera sp.7, Hypoponera sp.8, Odontomachus scalptus and Pachycondyla constricta) and 18 species (33.96\%) were collected only once (singletons) (Fig. 2). A great range in number of species per sample was observed: the samples yielded between 1 and 14 species, with a mean of 6.67 ponerine ant species per sample (Fig. 3). Most species (58.49\%) occurred in just one season ( 9 exclusively during the dry season and 22 species during the

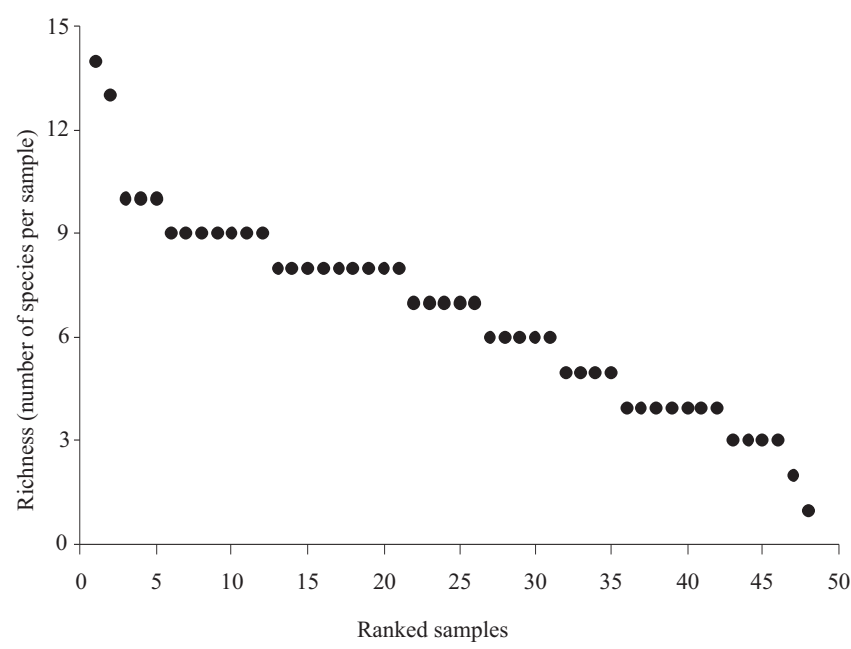

Fig. 3. Distribution of the number of ponerine ant species per sample in 48 leaf-litter sample units in ECFPn, Caxiuanã, Brazil. 
Table I. Composition and abundance (number of records) of the ponerine ant species collected in 48 leaf-litter samples from primary rainforest sites in ECFPn, Caxiuanã National Forest, Pará State, Brazil, during the peak of dry season (October, 2003) and beginning of rainy season (January, 2004).

\begin{tabular}{|c|c|c|c|c|c|c|c|}
\hline Tribes/species & Oct $/ 2003$ & $\mathrm{Jan} / 2004$ & Total & Tribes/species & Oct $/ 2003$ & Jan/2004 & Total \\
\hline Ponerini & & & & Ponerini (cont.) & & & \\
\hline Anochetus diegensis Forel, 1912 & 0 & 3 & 3 & Odontomachus brunneus (Patton, 1894) & 3 & 3 & 6 \\
\hline Anochetus horridus Kempf, 1964 & 4 & 7 & 11 & Odontomachus caelatus Brown, 1976 & 0 & 1 & 1 \\
\hline Anochetus mayri Emery, 1884 & 4 & 8 & 12 & Odontomachus haematodus (Linnaeus, 1758) & 3 & 2 & 5 \\
\hline Anochetus targionii Emery, 1894 & 2 & 3 & 5 & Odontomachus meinerti Forel, 1905 & 2 & 1 & 3 \\
\hline Hypoponera sp. 1 & 23 & 21 & 44 & Odontomachus scalptus Brown, 1978 & 11 & 3 & 14 \\
\hline Hypoponera sp. 2 & 7 & 10 & 17 & Odontomachus sp. 10 & 1 & 1 & 2 \\
\hline Hypoponera sp. 3 & 4 & 5 & 9 & Odontomachus sp. 9 & 2 & 0 & 2 \\
\hline Hypoponera sp. 4 & 2 & 0 & 2 & Pachycondyla arhuaca (Forel, 1901) & 4 & 2 & 6 \\
\hline Hypoponera sp. 5 & 8 & 0 & 8 & Pachycondyla constricta (Mayr, 1884) & 13 & 11 & 24 \\
\hline Hypoponera sp. 6 & 15 & 3 & 18 & Pachycondyla crenata (Roger, 1861) & 1 & 0 & 1 \\
\hline Hypoponera sp. 7 & 21 & 21 & 42 & Pachycondyla ferruginea (Smith, F., 1858) & 1 & 0 & 1 \\
\hline Hypoponera sp. 8 & 0 & 13 & 13 & Pachycondyla harpax (Fabricius, 1804) & 6 & 1 & 7 \\
\hline Hypoponera sp. 9 & 3 & 5 & 8 & Pachycondyla impressa (Roger, 1861) & 1 & 0 & 1 \\
\hline Hypoponera sp. 10 & 2 & 5 & 7 & Pachycondyla lenis (Kempf, 1961) & 0 & 3 & 3 \\
\hline Hypoponera sp. 11 & 0 & 4 & 4 & Pachycondyla mesonotalis (Santschi, 1923) & 0 & 1 & 1 \\
\hline Hypoponera sp. 13 & 1 & 1 & 2 & Pachycondyla sp. 1 & 1 & 0 & 1 \\
\hline Hypoponera sp. 14 & 4 & 0 & 4 & Pachycondyla sp. 2 & 0 & 1 & 1 \\
\hline Hypoponera sp. 15 & 0 & 1 & 1 & Pachycondyla sp. 3 & 0 & 3 & 3 \\
\hline Hypoponera sp. 16 & 0 & 2 & 2 & Pachycondyla stigma (Fabricius, 1804) & 1 & 2 & 3 \\
\hline Hypoponera sp. 17 & 0 & 2 & 2 & Pachycondyla unidentata (Mayr, 1862) & 3 & 0 & 3 \\
\hline Hypoponera sp. 18 & 0 & 1 & 1 & Pachycondyla venusta (Forel, 1912) & 0 & 1 & 1 \\
\hline Hypoponera sp. 19 & 0 & 1 & 1 & Pachycondyla verenae Forel, 1922 & 0 & 1 & 1 \\
\hline Hypoponera sp. 20 & 0 & 1 & 1 & Simopelta sp. 1 & 0 & 1 & 1 \\
\hline Hypoponera sp. 21 & 0 & 1 & 1 & Platythyreini & & & \\
\hline Hypoponera sp. 22 & 0 & 1 & 1 & Platythyrea sinuata (Roger, 1860) & 0 & 1 & 1 \\
\hline Leptogenys pusilla (Emery, 1890) & 0 & 2 & 2 & Thaumatomyrmecini & & & \\
\hline Leptogenys sp. 1 & 0 & 1 & 1 & Thaumatomyrmex sp. 1 & 2 & 2 & 4 \\
\hline Odontomachus bauri Emery, 1892 & 1 & 1 & 2 & Total number of records & 156 & 164 & 320 \\
\hline
\end{tabular}

rainy season). Only $41.51 \%$ (22) of species were shared between the dry and rainy seasons. Twenty one (39.62\%) species were found at only a single site (3 exclusively in IMA I; 2 in IMA II; 4 in IMA III; 5 in IMA IV; 6 in IMA V and 1 in IMA VI) and only six species (11.32\%) were found in all sites.

Species abundance (frequency of occurrence) and richness were associated with leaf-litter volume. The linear regression analysis indicated that the species abundance $\left(\mathrm{r}^{2}=\right.$ $0.37, \mathrm{t}=2.44, \mathrm{p}=0.035)($ Fig. 4$)$ and richness $\left(\mathrm{r}^{2}=0.38, \mathrm{t}=\right.$ $5.28, \mathrm{p}<0.01$ ) (Fig. 5) increased linearly with leaf-litter volume. The total volume of sifted leaf-litter submitted to extractors was $242,200 \mathrm{ml}$, the mean volume per transect was $5,045.83 \mathrm{ml}$ and per site volume was $20,183.33 \mathrm{ml}$. Thus, we got seven ponerine ant species per sample unit and 27 occurrences per 100 ha plot, on average, in the primary forests of Caxiuanã, by using Winkler extractors.

Species composition. The NMDS indicated higher similarity of species composition between the dry samples (October), as these samples were slightly more aggregated than the rainy ones (January), in the obtained configuration (Fig. 6).

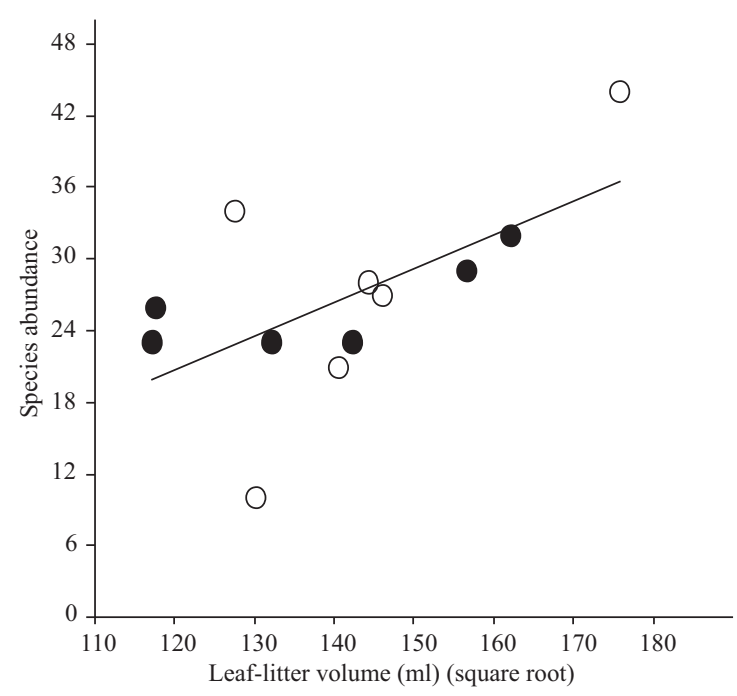

Fig. 4. Relation between the ponerine ant species abundance and leaf-litter amount (sifted leaf-litter volume transformed in square root). Black circles represent samples of dry season (October) and white circles those of rainy season (January). 


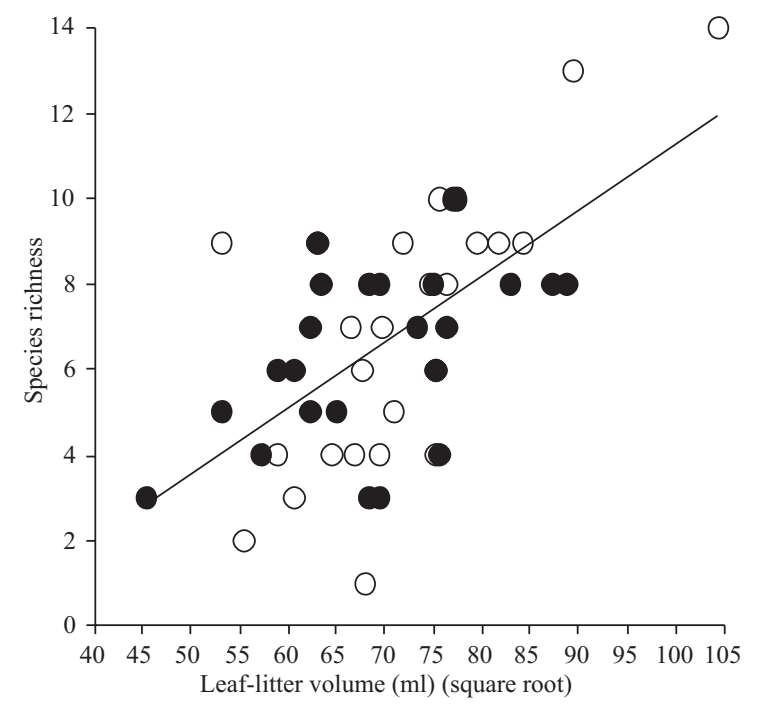

Fig. 5. Relation between the ponerine ant species richness and leaf-litter amount (sifted leaf-litter volume transformed in square root). Black circles represent samples of dry season (October) and white circles those of rainy season (January).

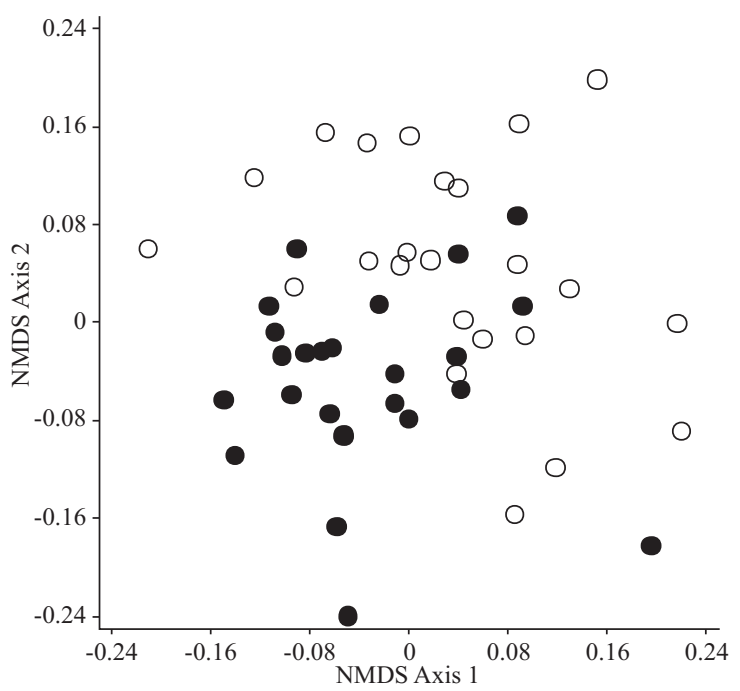

Fig. 6. Sampling scores projection according to ponerine ant species composition in non-metric multidimensional scaling (NMDS) ordination of 48 leaf-litter sample units from six primary rainforest sites in ECFPn, Caxiuanã, Brazil (Jaccard measure of association; stress $=0.35$ ). Black circles represent samples of dry season (October) and white circles those of rainy season (January).

The first and second NMDS dimensions were most representative of variation in species composition (Table II). There were few superposed points in the ordination configuration, suggesting a relatively low similarity between the collection periods (Fig. 6). The arrangement of data points can be explained by the representativeness of some species in a determined collect period. Hypoponera sp.5, Hypoponera sp.6, Odontomachus scalptus, Pachycondyla constricta and $P$. harpax species were more abundant (relatively) in the dry samples; whereas Anochetus horridus, A. mayri and
Hypoponera sp.8 yielded higher eigenvalues in the rainy samples.

The ponerine ant species composition varied with leaflitter quantity for one of the two NMDS axes. The linear correlation analysis described a significant amount of variation in the species composition (eigenvalues of NMDS Axis 2) along a leaf-litter volume gradient. However, axis 1 showed no significant correlation, but the probabilistic value approached significance level (Table II).

The average community similarity measured by Jaccard index was low $(\mu=0.27$ ), ranging from 0.00 (even among samples from the same IMA and collection period) to 0.75 (found only among samples from different IMAs and periods).

Table II. Coefficients of determination to ordination dimensions $\left(\mathrm{r}^{2}\right)$ and to Person's correlation ( $r$ ) between ponerine ant species composition (Axes 1 and 2 produced by non-metric multidimensional scaling) and sifted leaflitter volume (transformed in square root).

\begin{tabular}{crc}
\hline Variables & Axis 1 (NMDS) & Axis 2 (NMDS) \\
\hline $\mathrm{r}^{2}$ (NMDS) & 0.260 & 0.230 \\
$\mathrm{r}$ (Pearson) & -0.270 & 0.290 \\
$\mathrm{p}$ (Pearson) & 0.067 & $0.047^{*}$ \\
\hline
\end{tabular}

* Significance level $\mathrm{p}<0.05$.

\section{DISCUSSION}

Species abundance and richness. As expected, the sampling effort used in this study yielded high ponerine ant species abundance ( 320 occurrences) and richness (53 species) in the leaf-litter stratum of primary forest in eastern Amazonia. Other work conducted in Caxiuanã primary forests (Overal et al. 1997; Souza et al. 2007; 2009; Bastos \& Harada 2009) indicates high ponerine species richness, too, but shows fewer species than the present results. Overal et al. (1997) investigated ants assemblages of periodically inundated and "terra-firme" forests collecting by means of tuna, honey and biscuit baits, entomological net sweeping the vegetation, Berlese funnels (leaf-litter samples), and hand-collecting. Twenty-one ponerine species were found, most nesting in the soil and foraging in the leaf-litter or soil. However, according to authors, there were preliminary results obtained without a standardized sampling protocol. Using Winkler extractors and pitfall traps (of the same TEAM/ Caxiuanã Project Protocol), Souza et al. (2007; 2009) analyzed the diversity of Pachycondyla species collected during the dry season. Fifteen species were found, 6 exclusively from pitfall traps and 4 from Winkler extractors. Bastos \& Harada (2009) studied the distribution of Odontomachus species in the same sites during a year (January 2003 - January 2004) using Winkler extractors, and found 10 species that tended to spread distinctly between the seasons.

The relatively high fraction of unique species $(\sim 34 \%)$ and the low fraction of numerically dominant species $(\sim 13 \%)$ cor- 
roborate what is expected to leaf-litter ant community in Neotropical region with the employed methods (Olson 1991; Longino et al. 2002; Leponce et al. 2004). Most of the rare species belong to the genus Hypoponera and possess the typical morphologic characters of cryptic ants with hypogaeic habits that occasionally forage on the soil surface (King et al. 1998; Silvestre 2000; Hoffmann \& Andersen 2003; Silva \& Silvestre 2004; Delabie et al. 2007). This rarity strongly suggests that the use of the mini-Winkler method select the mesofauna in leaf-litter layer and soil surface at sampling time. Some epigaeic species of Dinoponera, Odontomachus and Pachycondyla, although expected to be present, were absent or seldom recorded due other selectivity in the mini-Winkler method. The small standard mesh-bag gap size for Winkler traps (diameter $=0.4 \mathrm{~cm}$ ) may explain the rarity or absence of these species, usually with individuals larger than the meshbag holes, these being better sampled with pitfall traps (Olson 1991; Souza et al. 2007). Ants of leaf-litter were better sampled by using pitfall traps and mini-Winkler extractors, in Caxiuanã primary forests (Souza et al. 2007, 2009). As these two sampling methods are complements (Souza et al. 2007, 2009) and the most ponerine species occurred in just one season ( 9 species exclusively in dry season and 22 in rainy season), we suggest to use sampling designs including pitfall, Winkler and others methods during two seasons and along several sites to assess and monitoring the leaf-litter ant diversity in Amazonian primary forests.

This study showed that leaf-litter amount positive correlates with ponerine ant abundance and richness. The results suggest that the heterogeneous content of leaf-litter amount directly affects the diversity of ants that inhabit or forage on the soil surface of Amazonian forests. Fagundes (2003) also found a positive relationship between the number of Ponerinae ants and leaf-litter quantity, but he did not treat the community at the specific level. The high local ant diversity in tropical rainforests can be related to an ample variety of nest sites available to specialized ants (Benson \& Harada 1988). Our survey supports this hypothesis, considering the ponerine ants from leaf-litter of primary forests in eastern Amazonia. Patches with higher leaf-litter volume on forest soil have more physical resources (e.g., available sites for nest or shelter) (Shik \& Kaspari 2010) and food for ants, which are attractive to colony establishment and development and foraging of predatory species (McGlynn \& Kirksey 2000). Further, these patches provide many shelter sites, since cryptic species are obviously more difficult to see in deep leaf-litter (Blüthgen \& Feldhaar 2010).

In view of natural disturbances, in time and space, of leaflitter density in Neotropical forests, the structure of ant communities tends to be significantly modified (Byrne 1994; Campos et al. 2007). Moreover, the leaf-litter ant communities presents a dynamic of re-colonization and nest relocation according to this environmental variability, especially due to preferences for some resources (nests or food) (McGlynn 2006; Campos et al. 2007; Blüthgen \& Feldhaar 2010). Therefore, the high faunistic dissimilarity found at small scales strongly suggests that local scattering of leaflitter density is highly heterogeneous. This aspect supports the coexistence of forest floor plants and mesofauna soil species, although it harms the locomotion of small arthropods and usually generates zones of ecological successions (Kaspari \& Weiser 1999; Sayer 2006; Campos et al. 2007). These factors help to explain the spatial and temporal changes, as well as the high local diversity, of ponerine ant communities in the leaf-litter stratum of the primary forests in Caxiuanã. Our results evidenced these ecological mechanisms. Biotic relations (as intra- and interspecific interactions) of the species were not analyzed spatially, but these also could be related to leaf-litter volumes (McGlynn \& Kirksey 2000).

Species composition. Collections with mini-Winkler extractors show high proportions of unique species, underlining their importance in studies of species composition (Olson 1991; Bestelmeyer et al. 2000). Some ecological surveys that assessed effects of environmental change on ant assemblages leaded no differences in the species richness and abundance, but it was true to species compositions (see Ribas \& Schoereder 2007). So, as suggesting Kaspari \& Majer (2000), the species composition might be an important structural variable of these assemblages. Our results suggest to use of quali- and quantitative methods to help us to assess the effects of environmental changes on ant assemblages, such as mini-Winkler to ponerine ants of leaf-litter.

We found a positive association between leaf-litter volume and ponerine ant species composition, indicating that leaf-litter composition could be a determinant factor for the presence of certain species (Armbrecht et al. 2004). As ants forage and nest according to local nutrient limitation and resource availability (McGlynn \& Kirksey 2000; McGlynn et al. 2007), and since leaves, small twig sticks, seeds and other special components are unequally distributed in the leaflitter, ants of different kinds or functional groups should also be heterogeneously distributed on the forest floor. For instance, when a species exploits immature ants in its diet, it is more probable to occur (foraging) in leaf-litter patches with high density of ant nests, where this resource abounds (McGlynn 2006). In order to understand the presence or absence of an ant species or functional group, we must also take into account the species biology and community interactions. Thus, the predatory behavior or competitive interactions for a specific resource may influence the presence or absence of an ant species at a given site (Ribas \& Schoereder 2002). For example, species of Thaumatomyrmex are specific predators of millipedes (Brandão et al. 1991), and the deterministic causes for millipede distribution therefore also likely influence distribution of their predators.

Co-existence of several species in a habitat can be explained by the relation between nesting habit and food resource preferences, which naturally affects niche differentiation in ant communities (Blüthgen \& Feldhaar 2010). For leaf-litter ponerine ants in Caxiuanã this hypothesis was confirmed, since the gradual increase of leaf-litter density creates microhabi- 
tats with prey items or other concentrated specific resources influencing community composition and supporting the coexistence of several species. The rare species of the genera Platythyrea, Simopelta and Thaumatomyrmex, which show peculiar natural history aspects, such as specific diets and predatory habits, were found only in samples with high leaflitter volumes.

The low faunistic similarity among relatively nearby samples collected at the same period, strongly suggests that environmental heterogeneity on a small scale (verified with the divergence in leaf-litter volumes) affects ponerine species distribution independent of (or with low dependence on) the spatial distances between sampling sites. Moreover, as leaf-litter availability appears to be heterogeneous, the leaflitter amount has shown to be an important factor in structuring ground-dwelling ponerine ant communities in eastern Amazonian rainforests.

\section{ACKNOWLEDGMENTS}

We thank the Ferreira Penna Scientific Station (ECFPn) and Programa de Pós-Graduação em Zoologia of the Universidade Federal do Pará and the Museu Paraense Emílio Goeldi for logistical support and permissions. We also thank the TEAM Caxiuanã Project (Tropical Ecology Assessment and Monitoring), of Conservation International, financed by the Gordon \& Betty Moore Foundation, as well as MPEG for logistical and financial supports. Special thanks to our fieldworkers and lab assistants, to William Overal (MPEG) for help with the English version of this manuscript, to Marcelo Thalês (MPEG) for preparing the map of the study area, and the constructive criticism and suggestions of anonymous referees to improve this manuscript. Financial support for the first author was provided by CAPES (Coordenação de Aperfeiçoamento de Pessoal de Nível Superior).

\section{REFERENCES}

Armbrecht, I.; I. Perfecto \& J. Vandermeer. 2004. Enigmatic biodiversity correlations: ant diversity responds to diverse resources. Science 304: 284-286.

Bastos, A. H. dos S. \& A. Y. Harada. 2009. O gênero Odontomachus Latreille, 1804, na Estação Científica Ferreira Penna, p. 525-536. In: P. L. B. Lisboa. (org.). Caxiuanã: desafios para a conservação de uma Floresta Nacional na Amazônia. Belém, Editora Museu Paraense Emílio Goeldi, 672 p.

Benson, W. \& A. Y. Harada. 1988. Local diversity of tropical and temperate ant faunas (Hymenoptera, Formicidae). Acta Amazonica 18: 275-289.

Bestelmeyer, B. D.; D. Agosti; L. E. Alonso; C. R. F. Brandão; W. L. Brown; J. H. C. Delabie \& R. Silvestre. 2000. Field techniques for the study of ground-dwelling ants: an overview, description, and evaluation, p. 122144. In: D. Agosti; J. D. Majer; L. E. Alonso \& T. R. Schultz (eds.). Ants: standard methods for measuring and monitoring biodiversity. Washington, Smithsonian Institution Press, 280 p.

Blüthgen, N. \& H. Feldhaar. 2010. Food and shelter: how resources influence ant ecology, p. 115-136. In: L. Lach; C. L. Parr \& K. L. Abbott (eds.). Ant Ecology. New York, Oxford University Press, 402 p.

Brandão, C. R. F.; J. L. M. Diniz \& E. M. Tomotake. 1991. Thaumatomyrmex strip millipedes for prey: a novel predatory behaviour in ants, and the first case of sympatry in the genus (Hymenoptera: Formicidae). Insectes Sociaux 38: 335-344.

Brühl, C. A.; M. Mohamed \& K. E. Linsenmair. 1999. Altitudinal distribution of leaf litter ants along a transect in primary forests on Mount Kinabalu, Sabah, Malaysia. Journal of Tropical Ecology 15: 265-277.

Byrne, M. M. 1994. Ecology of twig-dwelling ants in a wet lowland tropical forest. Biotropica 26: 61-72.

Campos, R. B. F.; J. H. Schoereder \& C. F. Sperber. 2007. Small-scale patch dynamics after disturbance in litter ant communities. Basic and Applied Ecology 8: 36-43.

Costa, J. P. R. \& J. C. Moraes. 2002. Médias mensais de variáveis meteorológicas (1996-1999), p. 225-232. In: P. L. B. Lisboa (org.). Caxiuanã: populações tradicionais, meio físico e diversidade biológica. Belém, Editora Museu Paraense Emílio Goeldi, 734 p.

Delabie, J. H. C. \& H. G. Fowler. 1995. Soil and litter cryptic ant assemblages of Bahian cocoa plantations. Pedobiologia 39: 423-433.

Delabie, J. H. C.; B. Jahyny; I. C. do Nascimento; C. S. F. Mariano; S. Lacau; S. Campiolo; S. M. Philpott \& M. Leponce. 2007. Contribution of cocoa plantations to the conservation of native ants (Insecta: Hymenoptera: Formicidae) with a special emphasis on the Atlantic Forest fauna of southern Bahia, Brazil. Biodiversity and Conservation 16: 2359-2384

Fagundes, E. P. 2003. Efeito de fatores do solo, altitude e inclinação do terreno sobre os invertebrados da serapilheira, com ênfase em Formicidae (Insecta, Hymenoptera) da reserva Ducke, Manaus, Amazonas, Brasil. Master Science Dissertation. Manaus, Instituto de Pesquisas da Amazônia - Universidade Federal do Amazonas, 79 p.

Fittkau, E. J. \& H. Klinge. 1973. On biomass and trophic structure of the Central Amazonia rain forest ecosystem. Biotropica 5: 2-14.

Folgarait, P. J. 1998. Ant biodiversity and its relationship to ecosystem functioning: a review. Biodiversity and Conservation 7: 1221-1244.

Hammer, Ø. \& D. A. T. Harper. 2010. PAST: Palaeontological Statistics, version 1.99. In: Ø. Hammer; D. A. T. Harper \& P. D. Ryan. PAST: paleontological statistics software package for education and data analysis. Available in: http://folk.uio.no/ohammer/past/download.html (accessed 31st March 2010).

Hammer, Ø; D. A. T. Harper \& P. D. Ryan. 2008. Multivariate Statistics. In: Ø. Hammer; D. A. T. Harper \& P. D. Ryan. PAST: paleontological statistics software package for education and data analysis. Available in: http://folk.uio.no/ohammer/past/multivar.html (accessed 15th January 2008).

Hoffmann, B. D. \& A. N. Andersen. 2003. Responses of ants to disturbance in Australia, with particular reference to functional groups. Austral Ecology 28: 444-464.

Kaspari, M. \& J. D. Majer. 2000. Using ants to monitor environmental changes, p. 89-98. In: D. Agosti; J. D. Majer; L. E. Alonso \& T. R. Schultz (eds.). Ants: standard methods for measuring and monitoring biodiversity. Washington, Smithsonian Institution Press, $280 \mathrm{p}$.

Kaspari, M. \& M. D. Weiser. 1999. The size-grain hypothesis and interspecific scaling in ants. Functional Ecology 13: 530-538.

Kaspari, M. \& S. P. Yanoviak. 2008. Biogeography of litter depth in tropical forests: evaluating the phosphorus growth hypothesis. Functional Ecology 22: 919-923.

King, J. R.; A. N. Andersen \& A. D. Cutter. 1998. Ants as bioindicators of habitat disturbance: validation of the functional group model for Australia's humid tropics. Biodiversity and Conservation 7: 16271638.

Lattke, J. E. 2003. Subfamilia Ponerinae, p. 261-276. In: F. Fernández (ed.). Introducción a las hormigas de la región neotropical. Bogotá, Instituto de Investigación de Recursos Biológicos Alexander von Humboldt, xxvi+398 p.

Leponce, M.; L. Theunis; J. H. C. Delabie \& Y. Roisin. 2004. Scale dependence of diversity measures in a leaf-litter ant assemblage. Ecography 27: 253-267.

Levings, S. C. 1983. Seasonal, annual, and among-site variation in the ground ant community of a deciduous tropical forest: some causes of patchy species distributions. Ecological Monographs 53: 435-455. 
Lisboa, P. L. B. 2002. A Estação Científica Ferreira Penna/ECFPn (19932000), p. 35-55. In: P. L. B. Lisboa (org.). Caxiuanã: populações tradicionais, meio físico e diversidade biológica. Belém, Editora Museu Paraense Emílio Goeldi, 734 p.

Longino, J. T.; J. Coddington \& R. K. Colwell. 2002. The ant fauna of a tropical rain forest: estimating species richness three different ways. Ecology 83: 689-702

Majer, J. D. \& J. H. C. Delabie. 1994. Comparison of the ant communities of annually inundated and terra firme forests at Trombetas in the Brazilian Amazon. Insectes Sociaux 41: 343-359.

McGlynn, T. P. 2006. Ants on the move: resource limitation of a litter-nesting ant community in Costa Rica. Biotropica 38: 419-427.

McGlynn, T. P.; D. J. Salinas; R. R. Dunn; T. E. Wood; D. Lawrence \& D. A Clark. 2007. Phosphorus limits tropical rain forest litter fauna. Biotropica 39: 50-53.

McGlynn, T. P. \& S. E. Kirksey. 2000. The effects of food presentation and microhabitat upon resource monopoly in a ground-foraging ant (Hymenoptera: Formicidae) community. Revista de Biología Tropical 48: 629-642.

Mertl, A. L.; K. T. R.Wilkie \& J. F. A. Traniello. 2009. Impact of flooding on the species richness, density and composition of amazonian litternesting ants. Biotropica 41: 633-641.

Olson, D. M. 1991. A comparison of the efficacy of litter sifting and pitfall traps for sampling leaf litter ants (Hymenoptera, Formicidae) in a tropical wet forest, Costa Rica. Biotropica 23: 166-172.

Overal, W. L.; A. Y. Harada \& B. M. Mascarenhas. 1997. As formigas, p. 369-379. In: P. L. B. Lisboa (org.). Caxiuanã. Belém, Editora Museu Paraense Emílio Goeldi, 440 p.

Philpott, S. M.; I. Perfecto; I. Armbrecht \& C. L. Parr. 2010. Ant diversity and function in disturbed and changing habitats, p. 137-156. In: L. Lach; C. L. Parr \& K. L. Abbott (eds.). Ant Ecology. New York, Oxford University Press Inc. 402 p.

Quiroz-Robledo, L. N. \& J. Valenzuela-González. 2007. Distribution of poneromorph ants (Hymenoptera: Formicidae) in the Mexican State of Morelos. Florida Entomologist 90: 609-615.

Ribas, C. R. \& J. H. Schoereder. 2002. Are all ant mosaics caused by competition? Oecologia 131: 606-611.

Ribas, C. R. \& J. H. Schoereder. 2007. Ant communities, environmental characteristics and their implications for conservation in the Brazilian Pantanal. Biodiversity and Conservation 16: 1511-1520.

Romero, H. \& K. Jaffe. 1989. A comparison of methods for sampling ants (Hymenoptera, Formicidae) in Savannas. Biotropica 21: 348-352.
Santos, M. S.; J. N. C. Louzada; N. Dias; R. Zanetti; J. H. C. Delabie \& I. C. Nascimento. 2006. Riqueza de formigas (Hymenoptera, Formicidae) da serapilheira em fragmentos de floresta semidecídua da Mata Atlântica na região do Alto do Rio Grande, MG, Brasil. Iheringia, Série Zoologia 96: 95-101.

Sayer, E. J. 2006. Using experimental manipulation to assess the roles of leaf litter in the functioning of forest ecosystems. Biological Reviews 81: $1-31$.

Schmidt, C. A. 2008. The rough guide to Ponerine ants. Available in: http://www.ponerine.org/ponerines.shtml (accessed at January, 24, 2008).

Schütte, M. S.; J. M. Queiroz; A. J. Mayhé-Nunes \& M. P. S. Pereira. 2007. Inventário estruturado de formigas (Hymenoptera, Formicidae) em floresta ombrófila de encosta na ilha da Marambaia, RJ. Iheringia, Série Zoologia 97: 103-110.

Shik, J. Z. \& M. Kaspari. 2010. More food, less habitat: how necromass and leaf litter decomposition combine to regulate a litter ant community. Ecological Entomology 35: 158-165.

Silva, R. R. \& R. Silvestre. 2004. Riqueza da fauna de formigas (Hymenoptera: Formicidae) que habita as camadas superficiais do solo em Seara, Santa Catarina. Papéis Avulsos de Zoologia 44: 1-11.

Silvestre, R. 2000. Estrutura de comunidades de formigas do Cerrado. Doctor Science Thesis. Ribeirão Preto, Universidade de São Paulo Faculdade de Filosofia, Ciências e Letras de Ribeirão Preto, 216 p.

Souza, J. L. P.; C. A. R. Moura; A. Y. Harada \& E. Franklin. 2007. Diversidade de espécies dos gêneros de Crematogaster, Gnamptogenys e Pachycondyla (Hymenoptera: Formicidae) e complementaridade dos métodos de coleta durante a estação seca numa estação ecológica no estado do Pará, Brasil. Acta Amazonica 37: 649-656.

Souza, J. L. P.; C. A. R. Moura; \& E. Franklin. 2009. Complementaridade de métodos e redução de esforço amostral em inventários de Crematogaster, Gnamptogenys e Pachycondyla (Hymenoptera: Formicidae) na Floresta Nacional de Caxiuanã, p. 493-503. In: P. L. B. Lisboa. (org.). Caxiuanã: desafios para a conservação de uma Floresta Nacional na Amazônia. Belém, Editora Museu Paraense Emílio Goeldi, $671 \mathrm{p}$

Vasconcelos, H. L. 1999. Effects of forest disturbance on the structure of ground-foraging ant communities in central Amazonia. Biodiversity and Conservation 8: 409-420.

Vasconcelos, H. L.; A. C. C. Macedo \& J. M. S. Vilhena. 2003. Influence of topography on the distribution of ground-dwelling ants in an Amazonian forest. Studies on Neotropical Fauna and Environment 38: 115-124.

Received 22/12/2010; accepted 3/12/2011

Editor: Márcio Roberto Pie 